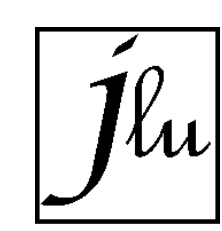

Jurnal Luminous:

E-ISSN 2715-6990

Riset Ilmiah Pendidikan Fisika

P-ISSN 2715-9582

Vol. 1 No. 1 (2020) 45-50

Januari 2020

https://jurnal.univpgri-

palembang.ac.id/index.php/luminous

\title{
PENGARUH MODEL PEMBELAJARAN GUIDED INQUIRY BERBANTUAN ALAT PERAGA TERHADAP KEMAMPUAN PEMECAHAN MASALAH SISWA SMA Yumita Devi Septiani ${ }^{1 *}$, Patricia Lubis ${ }^{2}$, Dwi Ratnaningdyah ${ }^{3}$ \\ 1,2,3 Prodi Pendidikan Fisika, FKIP, Universitas PGRI Palembang \\ 1'mitaplg17@gmail.com, 2patricialubis@gmail.com, 3dwi.dyalovai@gmail.com
}

\begin{abstract}
Abstrak
Penelitian ini mempunyai tujuan ada atau tidak pengaruh model pembelajaran Guided Inquiry berbantuan alat peraga terhadap kemampuan pemecahan masalah fisika siswa SMA Negeri 10 Palembang. Metode penelitian yang digunakan yaitu metode Quasi Experimental Design dengan Posttest Only Control Group Design. Variabel penelitian terdiri dari variabel terikat yaitu kemampuan pemecahan masalah dan variabel perlakuan adalah model pembelajaran Guided Inquiry berbantuan alat peraga.populasi dari penelitian ini adalah seluruh siswa kelas XI MIA di SMA Negeri 10 Palembang yang berjumlah 256 siswa. Teknik yang digunakan sampling purposive untuk menentukan sampel dengan jumlah 74 siswa yang terbagi menjadi dua kelas yaitu kelas XI MIA 2 yang berjumlah 37 siswa sebagai kelas eksperimen akan diberikan perlakuan model pembelajaran guided inquiry berbantuan alat peraga dan siswa kelas XI MIA 3 berjumlah 37 siswa sebagai kelas kontrol menggunakan pembelajaran konvensional. Teknik pengumpulan data menggunakan teknik tes essay dengan jumlah 5 soal. Teknik analisis yang digunakan dalam penelitian ini adalah uji-t pihak kanan dengan taraf signifikan $\alpha=0,05$ didapat ttabel sebesar 1,67 dan thitung sebesar 6,34 . Berdasarkan hasil perhitungan data artinya ada pengaruh signifikan penggunaan model pembelajaran guided inquiry berbantuan alat peraga terhadap kemampuan pemecahan masalah fisika siswa SMA Negeri 10 Palembang.
\end{abstract}

Kata Kunci: Guided Inquiry, Kemampuan Pemecahan Masalah

(C) 2020 Pendidikan Fisika FKIP UPGRI Palembang

\section{PENDAHULUAN}

Fisika sebagai salah satu rumpun ilmu IPA, pada hakikatnya juga terdiri atas aspek produk dan proses. Sebagai sebuah produk, fisika merupakan sekumpulan pengetahuan tentang fakta, konsep, generalisasi, prinsip, teori dan hukum fisika. Sementara sebagai suatu proses, fisika merupakan serangkaian proses ilmiah yang dilakukan dalam 
menemukan pengetahuan-pengetahuan tentang fisika (Azmi, et al 2016). Beberapa konsep fisika yang abstrak seringkali menjadi kendala bagi guru dalam menyampaikan materi kepada peserta didik. Kesalahan guru dalam memilih strategi pembelajaran dapat menyebabkan siswa kurang tertarik pada pembelajaran sehingga berdampak pada kurangnya motivasi dan keaktifan siswa selama proses belajar mengajar.

Berdasarkan hasil wawancara peneliti di SMA Negeri 10 Palembang, peserta didik menyatakan bahwa proses pembelajaran fisika berlangsung pasif, dimana peserta didik hanya sebagai pendengar informasi yang diberikan oleh guru. Selain itu, selama melakukan proses pembelajaran, guru jarang menggunakan media sebagai pendukung pembelajaran fisika. Konsep fisika sulit dimengerti membuat peserta didik beranggapan bahwa pelajaran fisika sulit sehingga menurunkan motivasi peserta didik yang berdampak pada kurangnya tingkat kemampuan pemecahan masalah fisika siswa. Penggunaan fasilitas sekolah seperti laboratorium dan infokus juga kurang maksimal. Melalui wawancara peneliti dengan salah satu Guru Fisika SMA Negeri 10 Palembang.

Pada hakikatnya mengajar fisika merupakan usaha untuk memilih strategi mendidik dan mengajar sesuai dengan materi yang akan disampaikan, dan upaya untuk menyediakan kondisi-kondisi dan situasi belajar fisika yang kondusif. Guru mempunyai kewajiban dalam menentukan dan menerapkan model dan metode apa yang dapat menarik perhatian siswa sehingga siswa aktif ketika belajar. Selain penggunaan model pembelajaran yang tepat, salah satu penggunaan media juga diperhatikan. Oleh karena itu peneliti merasa cocok menggunakan alat peraga sebagai medianya dengan menggunakan model pembelajaran guided inquiry.

Guided Inquiry "merupakan kegiatan pembelajaran yang melibatkan secara maksimal seluruh kemampuan siswa untuk mencari dan menyelidiki sesuatu secara sistematis, kritis, dan logis sehingga mereka dapat merumuskan sendiri temuannya dari sesuatu yang dipertanyakan" (Syarifudin, 2017:66)

Untuk menciptakan pemecahan masalah siswa menjadi meningkat, maka diperlukan juga suatu media pembelajaran yang dapat membantu agar proses pembelajaran menjadi mudah, menyenangkan efektif dan efisien serta tercipta suasana belajar yang aktif yaitu dengan alat peraga. Menurut Sudjana dalam jurnal (Atrisna \& Lubis, 2017:53) Alat peraga pembelajaran adalah alat bantu yang digunakan untuk menciptakan proses belajar mengajar yang lebih efektif. Dari uraian ini dapat disimpulkan bahwa penggunaan alat 
peraga juga mempengaruhi kemampuan pemecahan masalah siswa.

Kemampuan pemecahan masalah diukur menggunakan 5 indikator Menurut Heller \& Heller dalam jurnal (Ratnaningdyah D. 2017:2) secara garis besar indikator kemampuan pemecahan masalah fisika terdiri dari sebagai berikut: Memahami masalah, Menggambarkan masalah dalam istilah fisika, Merencanakan solusi, Menggunakan solusi dan Mengevaluasi solusi.

Penelitian yang terikat dengan model pembelajaran guided inquiry telah banyak dilakukan oleh peneliti diantaranya oleh Sayyadi et al (2016), Hertiavi et al (2010), Aji et al (2017).

Berdasarkan pada penjelasan diatas, sasaran penelitian ini adalah menerapkan pengaruh model pembelajaran Guided Inquiry berbantuan Alat Peraga terhadap Kemampuan Pemecahan Masalah Fisika Siswa SMA Negeri 10 palembang.

\section{METODE}

Jenis penelitian yang digunakan dalam penelitian ini adalah penelitian kuantitatif dengan metode Quassy Eksperimen Design dengan menggunakan desain Posttest Only Control Group Design dalam penelitian ini digunakan dua kelompok sampel yang dipilih berdasarkan rekomendasi guru, satu kelompok diberi perlakuan (treatment) dan satu kelompok yang lain tidak diberi perlakuan.

Bentuk desainnya adalah sebagai berikut:

\begin{tabular}{|lll|}
\hline E: & $X$ & 0 \\
C: & & 0 \\
& & \\
\hline
\end{tabular}

Sumber: Ali azrori (2014:116)

Populasi dalam penelitian ini adalah seluruh siswa kelas XI MIA di SMA Negeri 10 Palembangtahun pelajaran 2019/2020 yang berjumlah 256 siswa. Pengambilan data sampel dalam penelitian ini dengan menggunakan teknik Sampling Purposive, Oleh karena itu, diperoleh sampelnya adalah dua kelas yaitu kelas XI MIPA 2 yang berjumlah 37 siswa sebagai kelas eksperimen dan XI MIPA 3 yang berjumlah 37 siswa sebagai kelas kontrol.

Teknik analisis data tes menggunakan uji normalitas data untuk melihat apakah data terdistribusi normal atau tidak dengan menggunakan rumus chi kuadrat, uji homogenitas untuk mengetahui apakah data memiliki varians yang homogen setelah itu melalukan hipotesis menggunakan statistic uji-t (uji pihak kanan) (Sugiyono, 2017:128).

\section{HASIL DAN PEMBAHASAN}

Penelitian ini dilakukan untuk melihat kemampuan pemecahan masalah siswa pada 
mata pelajaran fisika di kelas XI MIA 2 dan di kelas XI MIA 3 di SMA Negeri 10 Palembang. Hasil penelitian ini rata-rata tes akhir kemampuan pemecahan masalah siswa yang menggunakan model pembelajaran Guided Inquiry berbantuan alat peraga lebih besar dibandingkan dengan menggunakan model pembelajaran saintifik. Perbedaan tersebut terlihat dari nilai rata-rata untuk kelas eksperimen didapat sebesar 80,24 lebih besar dari kelas kontrol dengan nilai rata-rata sebesar 71,05. Dari hasil Posttest kemampuan pemecahan masalah siswa dapat dilihat presantase kelas eksperimen dan kelas kontrol berbeda, terlihat pada diagram berikut:

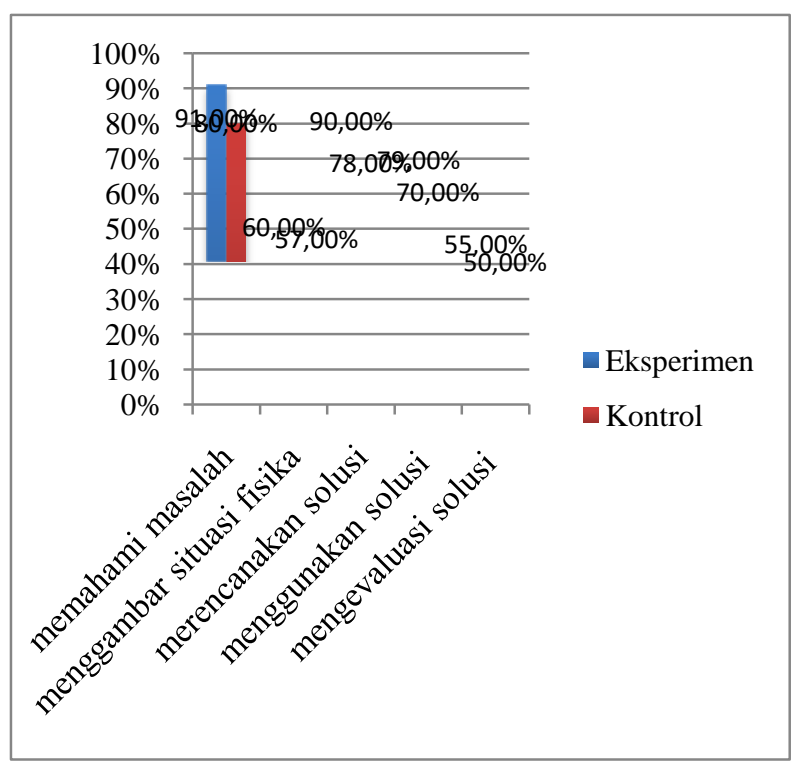

Gambar 1 Grafik Presentase

Berdasarkan gambar 1 terlihat bahwa presentase rata-rata indikator kemampuan pemecahan masalah kelas eksperimen lebih tinggi daripada kelas kontrol, hal ini dikarenakan proses pembelajaran dikelas eksperimen peneliti menggunakan model pembelajaran Guided Inquiry berbantuan alat peraga sedangkan dikelas kontrol peneliti hanya menggunakan model pembelajaran saintifik dan tidak menggunakan alat peraga. Untuk lebih jelasnya dapat dilihat pada rincian masing-masing indikator dibawah ini:

1. Pada indikator kemampuan memahami masalah, dikelas eksperimen menunjukkan bahwa persentase siswa memahami masalah sebesar $91 \%$ sedangkan pada kelas kontrol sebesar $80 \%$.

2. Pada indikator kemampuan menggambarkan masalah dalam istilah fisika, dikelas eksperimen menunjukkan bahwa persentase sebesar $60 \%$ sedangkan pada kelas kontrol 57\%.

3. Pada indikator kemampuan merencanakan solusi, dikelas eksperimen menunjukkan persentase siswa merencanakan solusi lebih tinggi jika dibandingkan dengan kelas kontrol, dimana persentase kelas eksperimen 
sebesar 90\%, sedangkan pada kelas kontrol sebesar $78 \%$.

4. Pada indikator kemampuan menggunakan solusi, dikelas eksperimen menyatakan bahwa persentase siswa dapat menggunakan solusi lebih tinggi dibandingkan dengan kelas kontrol. Persentase kelas eksperimen sebesar $79 \%$, sedangkan pada kelas kontrol sebesar $70 \%$.

5. Pada indikator kemampuan mengevaluasi solusi, dikelas eksperimen persentase siswa mengevaluasi lebih tinggi sebesar $55 \%$, sedangkan pada kelas kontrol sebesar $50 \%$.

Hal ini disebabkan "karena model pembelajaran inquiry ini berbasis penyelidikan, dimana peserta didik mencari sendiri jawaban dari permasalahan yang diberikan". Pembelajaran menggunakan model guided inquiry pada penelitian ini membuat siswa lebih aktif dalam belajar dan semangat dalam belajar sehingga mampu meningkatkan kemampuan pemecahan masalah siswa. Selain itu salah satu manfaat yang didapat dari model pembelajaran guided inquiry adalah dapat meningkatkan hasil belajar siswa dengan merancang dan menemukan sendiri konsep-konsep fisika akan membuat materi tersebut lebih lama tersimpan dalam ingatan siswa.

\section{KESIMPULAN DAN SARAN}

\section{Kesimpulan}

Dari hasil penelitian dan pembahasan dapat disimpulkan bahwa kemampuan pemecahan masalah siswa setelah diterapkan pembelajaran dengan menggunakan model pembelejaran guided inquiry berbantuan alat peraga dikelas XI MIA 2 sebagai kelas eksperimen ini tergolong baik, hal ini dapat dilihat dari nilai rata-rata tes akhir siswa adalah 80,24 sedangkan kelas XI MIA 3 sebagai kelas kontrol dengan menggunakan model pembelajaran saintifik dengan metode ceramah dan tanya jawab nilai rata-rata tes akhir adalah 71,05. Dari hasil uji hipotesis menggunakan uji-t dengan taraf signifikan 5\% diperoleh nilai $t_{\text {hitung }}=6,34$ dan $t_{\text {tabel }}=$ 1,67 artinya $t_{\text {hitung }}>t_{\text {tabel }}$ sehingga $H_{a}$ diterima dan $H_{o}$ ditolak. Berdasarkan hasil tersebut, maka dari penelitian ini dapat disimpulkan bahwa ada pengaruh model pembelajaran guided inquiry berbantuan alat peraga terhadap kemampuan pemecahan masalah siswa SMA Negeri 10 Palembang.

\section{Saran}

Berdasarkan hasil penelitian yang dilakukan maka peneliti menyarankan: Bagi peneliti lain, hendaknya mempersiapkan diri untuk lebih optimal dalam melakukan penelitian dan sebaiknya ada observer lain 
dalam membantu penelitian agar kelas menjadi lebih kondusif. Selain itu, diharapkan untuk peneliti selanjutnya dapat menemukan perbaikan dari kekurangan model pembelajaran guided inquiry sehingga dapat memperbaiki kekurangan dari hasil penelitian ini.

\section{DAFTAR PUSTAKA}

Ali, M., \& Asrori, M. (2014). Metodologi dan Aplikasi Riset Pendidikan. Jakarta: Bumi Aksara.

Atrisna, \& Lubis, P. (2017). Pengaruh Metode Demonstrasi dengan Menggunakan Alat Peraga Pipa Venturi Terhadap Pemahaman Konsep Fluida Dinamis Kelas XI di SMA Negeri 8 Palembang. PROSIDING SEMINAR NASIONAL PENDIDIKAN IPA 2017 , 52-55.

Azmi, M., Rahayu, S., \& Hikmawati. (2016).

Pengaruh Model Problem Based Learning dengan Metode Eksperimen dan Diskusi terdapat Hasil Belajar Fisika ditinjau dari Sikap IImiah Siswa Kelas $X$ MIPA SMA N 1 Mataram. Jurnal Pendidikan Fisika dan Teknologi, 86-94.

Ratnaningdyah, D. (2017). Upaya Melatihkan Kemampuan Pemecahan Masalah melalui Pembelajaran Fisika dengan Model Cooperative Problem Solving. Jurnal IImu Pendidikan Fisika, 2.
Sugiyono. (2017). Metode Penelitian dan Pengembangan. Bandung: Alfabeta.

Syarifudin. (2018). Pendidikan Agama Islam dan Budi Pekerti. Yogyakarta: Deepublish. 